\title{
Beyond Rule; Trust and Power as Capacities
}

\author{
Raffnsøe, Sverre
}

Document Version

Accepted author manuscript

Published in:

Journal of Political Power

DOI:

10.1080/2158379X.2013.809216

Publication date:

2013

License

Unspecified

Citation for published version (APA):

Raffnsøe, S. (2013). Beyond Rule; Trust and Power as Capacities. Journal of Political Power, 6(2), 241-260. https://doi.org/10.1080/2158379X.2013.809216

Link to publication in CBS Research Portal

\section{General rights}

Copyright and moral rights for the publications made accessible in the public portal are retained by the authors and/or other copyright owners and it is a condition of accessing publications that users recognise and abide by the legal requirements associated with these rights.

Take down policy

If you believe that this document breaches copyright please contact us (research.lib@cbs.dk) providing details, and we will remove access to the work immediately and investigate your claim.

Download date: 26. Apr. 2023
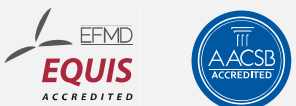


\section{Beyond Rule; Trust and Power as Capacities Sverre Rafnnsoe}

Journal article (Post print version)

This is an Accepted Manuscript of an article published by Taylor \& Francis in Journal of Political Poweron 03 Mar 2014, available online:

http://www.tandfonline.com/10.1080/2158379X.2013.809216.

Uploaded to Research@CBS: June 2016 


\title{
Beyond Rule
}

\section{Trust and Power as Capacities}

\author{
Sverre Raffnsøe \\ Department of Management, Politics and Philosophy, Copenhagen Business School, \\ Copenhagen, Denmark
}

(Abstract: Taking an approach that avoids comprehending power and trust as entities to be studied apart, the article insist on elucidating trust and power as they are enacted in their intimate and delicate relationship to each other and to other human and social phenomena of similar importance, such as knowledge and experience, gift-giving, hope, freedom and agency. To permit us to understand power and trust as interdependent dimensions, the article confronts the notions of power as command, coercion, control and calculation and develops a conception of power as a capacity. This permits to consider trusting as an exercise of power and an anticipatory affect. Trust is a resolve to bear an experienced risk by confiding in the new and unknown.)

Keywords: (power; trust; the virtual; affect; gift-giving)

During the past century, management and leadership have become an all-embracing concepts and phenomena with a profound and pervasive impact on the communities and the lives of individuals in the Western hemisphere. As soon as we have to confront and solve problems in organizations and society, to improve our performance or to reorganize, we look for better and more efficient ways not only to wield physical resources but also, and especially, to direct and conduct human efforts and behavior (Wren and Wren 2005: 3).

Management and leadership as ubiquitous activities imply an ongoing exertion of power. Pouvoir is a sine qua non of management and leadership (Nye 2008; Nye 2010, 305-332: 306). We have to "be able" (lat. potere) to do or to effect something. More specifically, we 
must have the ability or capacity to affect people in order to make them behave in ways they would not otherwise behave (Dahl 1957; Morris 1987/2002: 13).

Management also seems to presuppose something irreducible to power, however. Lately, it has become commonplace to draw attention to the fact that management heavily relies upon trust. Concurrently, sociological and economic theory, and especially managerial practice and theory, emphasize the importance of trust in management (Misztal 1996/98; Gambetta 1998). Trust is routinely marketed as an all-important value and a managerial resource, a not-to-betaken-for-granted resolve (Misztal 1996/98: 16) to show "confidence in or reliance on some quality or attributes of a person or thing, or the truth of a statement" (Oxford English Dictionary: entry for "trust"). Arguably, it helps to "facilitate cooperation," "lowers transaction costs," "promotes smooth and efficient market exchanges," and "improves" the ability of companies “to adapt and develop" (Wicks, Berman, and Jones 1999, 99-116: 99).

Indeed, trust is often considered a counter-concept to managerial power in the traditional sense: a concept that encapsulates all the positive effects of minimizing direct uses of power (Fukuyama 1995), while at the same time ensuring mutual obligations. Trust is associated with liberating and empowering employees and creating open spaces for innovation and expression. As we experience difficulty in exerting power within management and turn to trust, we seem to stumble upon an unexpectedly simple and efficient answer. In practice, this conception of the relationship between power and trust makes management and leadership inclined to commute incessantly back and forth between these realms. This shuttling back and forth makes management and leadership seem incoherent and untrustworthy. What is more, this division undermines trust, no matter how strongly the management may glorify it. Trust appears as an alternative domain into which the manager or the leader can escape when the domain of power fails. Shuttle management is detrimental since in practice management and leadership can no more do without power than it can do 
without trust. Both aspects of management and leadership must be present on a daily basis if a company is to prosper, an organization to function, or a country to assume a leading role. Therefore management and leadership need to replace the "either-or" perception of power and trust with a perception of "both-and." Management and leadership are in no way possible without power and the exercise thereof, but in the absence of trust, the manager's or leader's initiatives will be constantly resisted. However, if the manager and the leader do not exercise power and set the agenda, it will be equally impossible to win trust as a manager or a leader. In contradistinction to the described common tendency to 'segregate' between trust and power, a basic assumption of this article is that the two are closely interrelated and must be approached accordingly by management. The article purposes to re-examine and rethink trust and power in order to arrive at a more refined understanding of both notions, permitting us to cope with not only their mutual irreducibility but also with their inseparability and interdependency. This point is of consequence not only to the management of particular firms or organizations, but to leadership in and of society in general. In fact, whenever humans begin to lead, direct, instruct, manage, supervise, guide, and inspire each other, they must take heed of and respect the interrelatedness of power and trust. Upon closer inspection, the nature of power and trust is thus not quite self-evident (Dean 2012, 101-117: 101). For the layperson, the practitioner, and the theoretician, it seems necessary to pause and consider not only the notions of power and trust, but also their mutual relationship. To paraphrase James H. Read (Read J.H. 2010, 317-339: 319): How one understands power and trust shapes not only how one exercises power and shows trust, but also how one responds to the power and the trust of others. Still, the objective of the article is quite challenging, as there are serious impediments preventing its realization. 
The first section of this article examines an omnipresent, received notion of power as command, coercion, control, and calculation that forces us to imagine trust and power as separate realms and prevents a proper understanding and handling of trust.

The second section develops an alternative notion of power, permitting us to understand and relate to trust and power as complementary and interdependent dimensions. Here power appears as a capacity to affect the dispositions of others. When exercising power with this end in view, we begin to focus on another very real aspect of the world: the virtual.

Further developing the wide-ranging implications of this displacement, the third section shows how this more refined conception of power enables us to consider and relate to trusting as an active and deliberate exercise of power. In the wake of this more refined understanding of both power and trust, it is possible to conceive of trust as an anticipatory affect. In contrast to mere confidence, then, trust is essentially to be understood as a resolve to bear an actively experienced risk by confiding in the new and unknown. Closely associated with knowledge and hope, trust is thus essentially turned towards the new and is to be conceived of as a way of negotiating the future. Not only does trust anticipate and relate to the plane of the virtual. Trust may also be a way to actively influence the dispositions and the conduct of other people. Since trust affects people's dispositions to act, and also the way they express themselves, showing trust can be conceived of and practiced as an exercise of power and as way to direct people in a more refined manner.

The approach developed enables the articulation of a more refined understanding of potent power and leadership, closely associated with trust, in the final section. According to this conception, the exercise of power and leadership unintermittently experiences its own immediate and direct incapacity, but may be able to confront and overcome this impotence. Risking trust in the new, the exercise of power may become more potent, as it senses the threat and challenge posed by human freedom and independence - only to make use of them 
go gain power in a sense that is not opposed to but mediated through and enhanced by human independence and self-management.

\section{The InHERITED Notion OF PoWer AND ITS Relation to Trust}

If we are to perceive the correlation between power and trust and to take it into due account, we must reconsider the received notions of power in as much as they force us to end up with the "either-or" conception. We have to rethink these limited commonsensical notions to pave the way for a more subtle understanding of, and approach to, power and trust.

\section{The Received Concept of Power: Command, Coercion, Control and Calculation}

With regard to power, we are obliged to reconsider "the four Cs", which dominate the way we conceptualize power: command, coercion, and control, all closely linked to calculation. In the first place, we have to confront the received notions of power as Command (1) and Coercion (2). When we exercise power by commanding others, we tell them to do or to abstain from doing something specific. We express a certain wish, desire, or demand in such a way that we feel entitled to expect that they will comply with it.

If necessary, we may even back up our wish by threatening with certain unpleasant or even harmful sanctions (Hart 1979: 19). In cases like this, we achieve power by way of coercing other people. To command and to coerce may be very efficient ways to force other people to do things they would not otherwise have done. It permits the agent to obtain and to hold power over other people in an enduring, stable, and precise manner.

Exercising power in this manner even gives the agent the gratification of being or feeling in

Control (3). We direct the behavior of other people in such a way that they know exactly what 
to do, and in such a way that we know exactly what they will do and also know what to do if they do not do it. ${ }^{\text {ii }}$ If we exercise power in a way that makes us able to control other people, we are able to dominate them to such an extent that ultimately we appear to be the true cause of what they do. ${ }^{\text {iii }}$ We are able to have our way, and make our will prevail, to the extent that we appear to be the true and sovereign holders of power, so that the others are, at best, our auxiliary arms or tools.

Exercising power in this manner is closely associated with Calculation (4). By commanding, coercing, and controlling other people, we make sure that they do not act in unpredictable but predetermined ways. We see to it that we are able to foresee what is going to happen and are thus able to calculate the range of potential consequences.

\section{The Prevailing Notion of Rule}

Rather than being one option among many, power exercised and conceptualized as command, coercion, control, and calculation is to be regarded as the primary and norm-setting mode of power - at least, but not exclusively, in Western societies. Asserting itself against the existing network of feudal structures of dependence and rivalry (Luhmann 1989: 67), the Roman Catholic Church originally adopted this approach in order to establish itself as an overarching “counter-power" against the network of existing feudal structures of dependence (Raffnsøe 2001: 123). Subsequently, this approach was assumed and further developed by the more centralized form of monarchical power that appeared in the late Middle Ages (Raffnsøe 2003: 11-12). ${ }^{\text {iv }}$ In the theory and practice of the Holy See and of absolute monarchy, power is essentially exercised in the form of command, coercion, and control.

The modern Western European territorial states, and later nation states, continue to rest on the same notion of power. They remain centered on a supreme sovereign authority, forming the 
capital of the territory, whether this authority be an absolute monarch or the parliament of a representative democracy (Raffnsøe 2003). The established power structure creates a state of internal peace and agreement ${ }^{\mathrm{v}}$ as it expresses its will in the form of general standing mandatory orders. These orders are imperative statements to be obeyed by anyone concerned, simply because they are issued by someone in the position to do so. Moreover, they are orders that will be backed by sanctions if they are not complied with (Hart 1979: 18-25). Such commands establish a clear-cut, binary division of the world, since every kind of activity is classified either as a transgression of the imperatives or as a permitted activity that takes place within the limits prescribed. According to this long-standing juridical conception and institutionalization of power, power is essentially that which marks the boundaries within which we should remain, and hence it limits and represses us (Foucault 2003: 15). At the end of the day, to the extent that we follow this restrictive conception, power amounts to an ability to either put to death, or to let live (Foucault 1976: 178).

The conception of power as an expression of will mainly limiting other people prevails in a number of agenda-setting political thinkers and philosophers in the Western tradition, ranging from Bodin, Locke (Locke 1963), and Hume (Morriss 1987/2002: 15) over Rousseau (Rousseau: 1964: 379-80), Bentham (Bentham 1977; Bentham 1983), and Austin (Austin 1968; Raffnsøe 1996: 131) and right up to Freud (Foucault 2003: 15). It reaches an ideal typical expression in Hobbes, according to whom society is not to be presupposed, but is established through acts described as initiating commands issued by a central sovereign authority creating common-wealth ex nihilo, again and again, almost like "God in the creation" (Hobbes 1979: 82, 163-4). According to Hobbes, there is an intimate relation between “Obedience, Lawes, Peace, Charity, and civill Society” (Hobbes 1979: 173): “As men, for the atteyning of peace and conservation of themselves thereby, have made an Artificiall Man, which we call Common-wealth; so also have they made Artificiall Chains, 
called Civill Lawes, which they themselves, by mutuall covenants, have fastened at on end, to the lips of that Man, or Assembley, to whom they have given the Soveraigne Power; and to the other end to their own Ears" (Hobbes 1979: 263-64). This conception is also very much present in Kant (Kant 1976a: 30; Kant 1976d: 156) and Hegel (Hegel 1972: §231, §249, $\S \S 257-320)$.

Within this tradition the exercise of power is very closely associated with the notion of rule. Not only is the person or the authority that displays power and force expected to make the determining decisions; they are also supposed to be in charge by attending to the whole and creating and overseeing the unity of the entity that they govern. In addition to the literature and the practice previously mentioned, this notion of rule is presupposed and developed in an extensive literature that aims to instruct and counsel princes to enable them to assume the position of ruler. Inaugurated by Plato's seventh letter to Dionysius of Syracuse and Xenophon's Cyropaedia, an ongoing tradition of mirrors for princes finds a classical expression in St. Thomas's On Princely Government to the King of Cyprus (Aquinas 1974). According to this tradition, the ruler must govern by assuming the position of the helmsman (Aquinas 1974: 3). By virtue of his natural and acquired capabilities and merits, he should be able to rise above his fellow beings and exercise dominance. Assuming his natural position above the crew, the helmsman should be able to dominate them and ensure a steady course, as he takes command, indicates the common destination, and finds the means to reach this goal. Within the exercise and conceptualization of power described, certain aspects of power may seem to be brought forth, accentuated, and perfected (Dean 2012, 101-117). Here power primarily takes on the well-established and relatively stable form of a specific and limited version of "power over" (Morriss 1987/2002: 32-35) (Haugaard M. 2012, 353-358; Pansardi P. 2012, 73-89; Morriss 2012, 91-99; Pansardi 2012, 493-497; Haugaard M. 2012, 33-54). The relational aspect of power is openly played out, insofar as power is conceived as "having 
power over someone", or as "the ability of an actor, or a set of actors to constrain the choices available to another actor or set of actors in a nontrivial way". Indeed, this is the case whether they are constrained to their advantage or disadvantage, and whether the constraint is intentional or not (Allen 1999: 123). If power is primarily and essentially understood and exercised as power over someone, power takes the form of an open and demonstrative subordination and control of others (Morriss 1987: 32-33) To lean on the terminology developed by Weber: To understand the specificity of this kind of power, the comprehensive and relatively "amorphous" "concept of power (Macht)" is of little use. "More precise" is the concept of "Herrschaft", of imperative control, rule, domination, or rule (Weber and Winckelmann 1980: 28-29). To date, domination has been a dominating conception of power (Haugaard M. 2012, 33-54).

\section{Rule, Power, and Trust}

So, through a long and convoluted historical process, the notion of the ruler has become the point of reference for agents aspiring to power, as concurrently the concepts of command, coercion and control have come to dominate the way we understand and exercise power. There have been number of valid reason for adopting this now-classic notion of power. Exercising power in this fashion has ensured stability and predictability for the governing as well as the governed. Hobbes went so far as to claim that this vertical power formed the will and reason of human society and was essential to common wealth (Hobbes 1979: 81).

That said, the model has a number of drawbacks as well. Along with this mainly restrictive conception of power, a certain restricted conception of power has gained almost hegemonic status. It is quite a simple and crude model of power, as it tends to reduce power exercised over and through other human beings to a brutish sort of power at the far end of the spectrum. 
Power becomes similar to the force exerted by human beings over things that "gives the capacity to modify, use, consume or destroy them" (Foucault 1982: 217). Consequently, exercising power along the lines set out by this notion of power makes it very difficult to cope with challenges posed by the advent of self-management and freedom, in the endeavor to make positive use of this unforeseeable dynamic in various ways.

Moreover, as long as we act within this classical but very limited conception of power (let us call it Power I), it will be most difficult to perceive trust as a way to exercise power. When we effect something, or make something happen by showing trust, we do not force other people to make it happen or command them to carry it out. Nor do we necessarily check whether it happens. In so far as we choose to rely on trust, we take risks and accordingly we risk being disappointed (Luhmann 1973). We are simply no longer able to remain in command and in control in the traditional way. Machiavelli's The Prince bears witness to the insurmountable difficulties of inspiring trust that princes face as they try "to avoid" "being under the control of other people" and maintain control of their own people and territory (Machiavelli 1977: 65). Equally, the fact that Hobbes does not include trusting behaviour in his rather long list of forms of power given in chapter 10 of Leviathan (Leviathan 1979: 15051), indicates that he finds it hard to categorize and perceive trust as power. Rather, he perceives the need to keep them apart and tends to distinguish sharply between trust and power.

Not only is it hard to perceive trust as power if power in the limited sense forms an unquestioned starting premise. There is simply little room for trust at all, be it in theory or in practice. As long as we adhere to this limited and limiting conception of power, we implicitly remain within a social contract based not on trust, but on distrust. When trying to organize a coherent society, we begin with the assumption that others will always end up deceiving us, at least if we are unable to establish unanimously binding commands and back them up by force. 
As we strive to organize society, and to create community and cooperation, our starting point is the worst-case scenario, so to speak, and we begin to organize society accordingly.

Exercising power in the manner perpetuated in the Western tradition, we turn our back on the experience of risk that is inherent in trust and end up suppressing human freedom in order to eradicate the possibility that we may be deceived in the future.

As already indicated, Hobbes's Leviathan may serve as an outstanding example of the attempt to construct a confidence-inspiring social contract based on command, control, and recourse to force. In Hobbes' infamous state of nature, interpersonal trust seemed fatuous. He explicitly states that even "if a Covenant be made, wherein neither of the parties performe presently, but trust one another; in the condition of Meer Nature (which is a condition of Warre of every man against every man) upon any reasonable suspicion, it is Voyd" (Hobbes 1979: 196). However, "in such a condition, there is no place for Industry; because the fruit thereof is incertain; and consequently no Culture of the Earth; no Navigation, (...), no Knowledge of the face of the Earth; no account of Time; no Arts; no Letters; no Society; and which is worst of all, continual feare, and danger of violent death" (Hobbes 1979: 186). According to Hobbes, the covenant could only be binding "if there be a common Power set over them both, with the right and force sufficient to compel performance" "because the bonds of words are too weak to bridle men's ambition, avarice, anger, and other Passions, whithout the feare of some coercive Power" (Hobbes 1979: 196). Consequently, trust could only be inane "in a civil estate, where there is a Power set up to constrain those that would otherwise violate their faith" (Hobbes 1979: 196). In Hobbes' social philosophy, trust could thus only have a positive value and an honest sense on the basis of and within an already established pact construed as and able to maintain itself as a common coercive power. Trust then is first and foremost to be conceived as a willing consent to the covenant and to its ability to establish and maintain a mutually binding relation between protection and obedience to and 
within a coercive order. In Hobbes, trust essentially takes the form of a tacit consent to the stability of an unlimited 'power over'.

Concurrently, however, Hobbes demonstrated the fragility of the construct. According to him, distrust remained ever present, for instance as a ubiquitous "disposition" to "WARRE," affecting all fellow citizens at each and every moment (Hobbes 1979: 185-7).

Yet in his own pointed way, Hobbes simultaneously happens to demonstrate a general, basic, tragic irony inherent in this approach to power and trust. We strive to soothe our anxiety that we may be betrayed, and society fall apart, by creating and upholding a reliable and trustworthy social order that transcends this very menace, as it is based on protective measures against it. But by these very measures, we manage to conjure up precisely those spirits that we are trying to confine, to the effect that they re-emerge as ever-present forces. Unwittingly, then, we adopt an approach that resembles the ruler's line of action in King Lear (Shakespeare 1977). Trying to protect himself and make sure that he is cared for, King Lear ends up rejecting Cordelia, his daughter who is "closest at heart" and loves him most dearly (also according to the etymology of her name). Distancing himself from that which should have been closest to his heart, and from the one who could have supported him, the king finally finds himself utterly abandoned.

\section{An Alternative Notion of Power}

As a consequence of the received notion of power, we are forced to perceive and treat trust as a phenomenon situated outside the realm and the range of power. We can no longer consider ourselves to be rulers in the traditional sense of the word if we want to be able to conceive of trust as a kind of power. In order to make room for understanding trust as power, we must conceive of power in a different, more subtle and more encompassing way (Power II). 


\section{Power as a Capacity}

According to this more subtle conception, exercising power is not reducible to ruling. If we say that someone has power, we do not necessarily assert that he has power over and controls someone else. What we claim is that he has the power to do something or make something happen. Consequently, power must essentially be conceived of as a certain capacity or ability (Morriss 1987: 13; Barnes 1988: 2). To grasp the workings of power in this sense, power must be theorized as 'power to' (Haugaard M. 2012, 33-54; Barnes 1988; Allen 1999; Pansardi P. 2012, 73-89; Morriss 2012, 91-99; Pansardi 2012, 493-497). Even if "the locution 'power over' has a specific use of its own; it is not the general, and certainly not the main, way we talk of power" (Morriss 1987: 33). Before he finds it necessary to confine the exercise of power to the received notions of power as command, coercion, control, and calculation in order to constitute society, Hobbes in Leviathan characterizes "the power of a Man", "to take it Universally" as "his present means, to obtain some future apparent Good" (Hobbes 1979: 150); and thus the philosopher comes close to an ability-oriented approach to power. When we discuss the workings of power in more subtle ways, we discuss the power to do something.

A person does not have power, however, simply by virtue of the fact that he is able to have an impact of some kind, or exert some influence. Power is more than the ability to affect someone or something (Morriss 1987: 29). For if it were no more than that, then a noisy passer-by who provoked his assailant would have been in power. Power is a performative act (Austin 1980) in a more directive way than that, since the ability to do something must be understood as the ability to bring about or accomplish something more specific than just a change of some sort. Having power is also, and even essentially so, the ability to effect 
(Morriss 1987: 29). It is the ability to bring about or obtain some more or less specific outcome that does not necessarily pre-exist.

In other words, according to this more subtle and general conception of power (Power II), it should be understood as the capacity to affect someone or something, not just in any way, but in ways that effect or bring about certain outcomes, or at least make them more likely. ${ }^{\mathrm{vi}}$

\section{Dispositional Power}

With this more subtle understanding of power, we enter a new plane of existence (Deleuze 1996). We no longer relate directly or primarily to the level of factual states in the world, be they past, present, or even future states of affairs. When discussing capacities, we leave the plane of factual information and begin debating dispositions - that is, tendencies or liabilities for something to happen or propensities for doing something.

Yet it is not exceptional to enter this plane. Ryle draws our attention to the fact that "a number of the words that we commonly use to describe and explain people's behaviour signify dispositions and not episodes" (Ryle 1966: 112). According to Ryle, to say that a person knows something, for example, is not to say that he is in a particular state, but that he is able to perform certain things if need be. Moreover, Ryle argues that we use such terms for characterizing a wide range of objects, from atoms and matter to animals and men, as we are "constantly wanting to talk about what can be relied on to happen as well as to talk about what is actually happening" (Ryle 1966: 112). If we say, for instance, that a rubber band is "elastic", we point at a certain disposition or propensity. We indicate that the band is prone to bend and stretch if affected, and that it is likely to resume its original shape afterwards. Likewise, if we characterize a man as "choleric", we state that he is easily susceptible to 
anger, but not necessarily that he will be angry each and every time he is provoked, or that he will be angry right now.

In the extreme case, the choleric person may in fact never burst into a fit of anger, given that he is never sufficiently provoked, just as the rubber band may remain elastic during its entire existence without actually being forced to bend or stretch. Still, the dispositions may exist even if they are never triggered or put into action and therefore remain unobservable.

Dispositions per se belong to the realm of the "unobservable," even though it is normally to expect them to manifest themselves in what occurs and thus to be perceptible in that way. Power conceived as a capacity (Power II) also belongs to this same plane of existence, even though the concept refers specifically to the capacity to effect certain social dispositions. When we assert that someone has power, we claim that he or she has the capacity to affect others to the effect that that they become prone to doing certain things or behaving in certain ways.

\section{The Plane of the Virtual}

When addressing questions of power and dispositions, we leave the realm of the factual (Ryle 1966: 112). Instead of confining ourselves to paying attention to actual objects and the actual, we begin to focus on another very real aspect of the world: the virtual (Deleuze 1991: 42-3, 81; Deleuze 1996). The virtual does not present itself in the form of a certain "whatness" (Heidegger 1976; Heidegger 1980b) or exist in an intimate pure present (Derrida 1967; Derrida1972). Instead "the virtual" refers to that which makes itself felt as something that acts in and through the present considered as a Vorhandenheit, as something at hand (Heidegger $1979, \S 43 c)$. 
As a consequence, the virtual is not to be conceived of as the possible, but as that which effects and is felt through its effects. "It is more apparitional than empirical" (Massumi 2002: 135). The virtual is developed through, and works in, the present as a substance, or as a being and a force (virtus) that is operative within it (Leibniz 1969: 26-27). The virtual is a "coming into being, registering as becoming" (Massumi 2002: 135). This force constitutes the genetic condition of real experience (Deleuze 1991) as it continually modifies the given and forces it to reshape. Giving impetus to the present, the virtual not only sets it in motion, but causes it to unfold itself to the effect that it transcends itself, further developing in certain determinate directions. As an "outside coming in" (Massumi 2002: 135), the virtual makes itself felt when certain trends are coming into force. It acts as a normative influence, to the effect that it predisposes social reality to further develop in certain directions.

When discussing power issues, we focus on the virtual and the dispositional in the sense described as we try to investigate and unfold the level of prescription as the crucial aspect of social reality. We articulate a level upon which we establish guidelines for how it is that we, in interaction with the surrounding world, can emerge and leave our mark. This prescriptive level is a most genuine and important aspect of reality; with regard to power and trust it should be given precedence over the actual in so far as the actual is understood as that which is the case.

The prescriptive level is important, because it has a determining effect not only on what exists, but also on what we imagine possible, and also, therefore, on what is - on being in the broadest sense. Not only does the prescriptive in this sense gain precedence over the actual; it is seen as more important than the existing. The prescriptive has already played a guiding or piloting role as soon as the real can be known as an object of knowledge, as soon as one can imagine the possible as something that might happen, as soon as one can point out the 
potentially realizable as something one can hope for, or act in order to bring about (Raffnsøe 2002, Vol. III: 373).

According to the conceptualization of power as a capacity, we are capable of exercising power to the extent that we have the competence and the ability to affect others in ways that influence their dispositions, meaning their tendency and ability to unfold themselves as they behave and act in specific ways. In practice, then, power is exercised and is felt as an activity that affects a restructuring of other people's fields of actions. Power conceived of at the level of Power II is to be understood and analyzed as "a mode of actions upon actions" (Foucault 1982: 220). We exercise power to the extent that, through our activity and actions, we are capable of structuring other people's fields of possible actions.

Consequently, power is also to be conceived of as a capacity to "conduct conduct (conduire des conduites)" (Foucault 1984: 315). ${ }^{\mathrm{vii}}$ Power is the capability to direct the way people relate to themselves and behave, and it is the capacity to do so in and by the way we relate to and direct ourselves. In this way, power is inherently relational and characterizes social relations (Pansardi 2012, 493-497: 78; Pansardi P. 2012, 73-89: 493). By conducting our own and other people's conduct, we are able to produce certain effects, to make a certain range of not fully predefined outcomes more likely than others.

\section{Power as the Management of Freedom}

According to this view, then, the exercise of power is closely associated with the exercise/use of freedom. Since the exercise of power does not fully determine the outcome, power presupposes freedom conceived of as the absence of external impediments (liberty) (as for instance in Kant 1976b: 755) and as the possibility and ability to make choices according to our inner will (“essential," "inner,” or moral freedom) (Kant 1976a: 299; Kant 1976c: 78; and 
elsewhere). In as much as the exercise of power is a mode of action and (re)action upon the actions of others in which we try to overcome and govern the actions of others, yet another demanding conception of freedom presents itself as an active immanent condition of possibility for the exercise of power. It is freedom as conceived of in the request formulated by Kant and the Enlightenment for mankind's "emergence" from the easy state of "selfincurred immaturity" to which people tend, when, due to laziness or cowardice, they submit themselves to "alien guidance" (Kant 1976d: 53).

In this request, freedom confronts us in the form of a demanding challenge or obligation to renounce the easy dependence on external circumstance, and to seize power courageously and resolutely through an independent mode of reflection and action that permits us to overcome the initially given conditions and the impediments and demands they impose upon us. Freedom is understood as an ongoing challenge and obligation to become free, an obligation that we have to face and live up to as, by emancipating ourselves, we try to attain maturity (Kant 1976d; Raffnsøe 2010) and assume responsibility for ourselves (Butler 2005). This relative freedom serves as an internal but irreducible condition of possibility for the exercise of power. At the very heart of the power lie the "intransitivity (intransivité)" and irreducibility of freedom and "the insubmissiveness and unmanageability (rétivité)" of the will (Foucault 1984: 315). ${ }^{\text {vii }}$ The participants' reciprocal endeavor to overcome existing or potential unfreedom (or in its most extreme form, servitude) and attain maturity constantly challenges the existing power relations and provokes them to reaffirm themselves by unfolding themselves anew.

Superficially, then, power and freedom are contrary terms that may seem incompatible with one another. However, they are certainly not contradictions that exclude each other. Scrutinized more closely, the irreducible contrariness between power and freedom creates an ongoing tension and antagonism between them, an ongoing struggle to gain the upper hand in 
which they provoke each other mutually, thereby forcing each other to transgress the immediately given form. In contradistinction to the doctrine that more power entails less freedom and more freedom presupposes freedom from power, according to this analysis power and freedom may enhance one another, implying more freedom and power. The more freedom is asserted, the more power is forced to exert and expand itself, thereby gaining power over more. The more power is exercised as the capacity to influence the dispositions of others, the more it challenges freedom to reaffirm itself as a capacity to emerge as a mature human being by overcoming the challenges posed by alien guidance.

This conception of power tallies with Foucault's statement that power "is exercised only over free subjects, and only insofar as they are free" (Foucault 1982: 221). It is possible to account for the traditional notion and practice of power within this conception of power, but as a very crude form of power. Exercised and practiced as Power I, power is characterized by the fact that those in power take freedom into consideration, but primarily as a challenge to be minimized by restricting human freedom. As they reduce human beings to passivity, people exercising power in this manner may try to avoid resistance. When doing so, however, they first and foremost act directly upon human beings as objects that can be handled, modified, and used as such. They do not seriously and positively take into account the way people act and exert themselves. At the end of the day, this objectifying and mainly negative display of power in many respects comes close to the simple use of force, or even to violence (Arendt 1970). Reducing free subjects to subjugated objects, Power I amounts to the exercise of power in a crude and unproductive form.

\section{An Alternative Conception Of Trust}

\section{Trust versus Confidence}


Within the more refined notion of power developed here as Power II, trust can be perceived as a kind of power. Defined as something over and above mere confidence, showing trust may be enacted and perceived as a conscious and reflected way to exercise power. Simply having confidence in someone or something is a relatively unreflective form of conduct, in that it is the (usually pre-unconscious) adoption of an attitude to continue as before, to depend on a setting that has hitherto been experienced as unproblematic. By contrast, trust involves the adoption of a more active stance, which is especially called for within a modern context where many former familiarities are said to be eroded and selfmanagement is prevalent. Trust is the active resolve to rely and gamble on the reliability of other people or circumstances, despite experienced uncertainty and unpredictability. So unlike confidentiality, trust is a way of relating to and dealing with unfamiliarity and freedom, as it involves an active resolve to take risks, despite the awareness that one's expectations may be disappointed. Showing trust is essentially a venture, transcending not only what is the case, but also to some extent transcending past experiences (Luhmann 1973: 27). While confidence is oriented towards and determined by the past, trust is essentially oriented towards future not only in the sense of future expectations (Luhmann 1973: 20), but also in the sense of something essentially unpredictable that may be foreclosed in the future (Løgstrup 1997: 8-28). When we trust someone or something, we actively adopt the attitude to choose risk in anticipation of some future gain that we might not be prepared to predict (Solomon \& Flores 2001: chap. 2).

\section{Trust, Fear and Hope as Anticipatory Affective Attitudes}


With the active resolve to show trust, consequently we enter the plane of the dispositional and the virtual. We begin to give prominence to what can be relied on and what may reasonably be expected to happen, over what is actually the case. And we do so with an acute awareness of the risk involved, since an irreducible outside is entering the scene, most likely to shatter or surpass our expectations in various respects.

Hence, conceived of at this level, trust is essentially to be understood as actively trusting the new and unknown. The resolution to actively take a risk and leap into the future is motivated by the conviction that the future will meet and perhaps even surpass the given expectations. As a firm though emotional conviction turned towards the future, trust is closely related to “anticipatory affects (Erwartungsaffekte)" (Bloch 1985, Vol. I: 82-3) such as hope and fear, but in reverse ways. The dread that the future will bring us nothing (good) counters and restrains our ability to show trust in the present. In contrast, the longing for something (else) to come makes us more inclined to trust.

When we are afraid, what frightens us is less an already given definite past or present threat. What predominantly causes dread is, instead, the anticipation that something negative is going to happen, something terrible that we often cannot entirely predict, but which we cannot avert and must passively undergo. Being affected in this way by the expectation of an anticipated negative future seems to counteract the ability to trust. When predominant, an "anticipation of hurt or injury" (Ahmed 2004: 65) in a given situation makes it almost impossible to adopt a trusting attitude in and to the present.

By contrast, hope — an anticipatory being affected actively by, and yearning for, something that transcends the conditions given in predictable or unpredictable ways - not only counterbalances the tendency to be overwhelmed passively by fear, but concomitantly paves the way for trust. When hoping and trusting, we do not resign ourselves to our fate, as in the case of despair, sloth, and helplessness. Instead of being overwhelmed by the state of things 
as we find them and projecting that experience onto the future, we make the best of things as we relate to them as conditions for initiating something else that is still in its infancy. When hoping, we cannot help cherishing and being affected by dreams of "a better life ... that might be possible (das möglich wäre)" (Bloch 1985, Vol. I: 1). When adopting a trusting attitude, we are detecting whether experience supports anticipations to such an extent that we could, and maybe even should, take the risk of relying upon the experienced conditions, despite an experienced uncertainty. In both cases, however, the anticipation of further fulfillment moves us, as it forces us to reaffirm the given conditions, and ourselves, by reforming them.

\section{Trust as an Informed and Engaging Gift Giving}

When hoping and trusting, we anticipate and focus on an ontology of the yet-to-be as it is mediated through the given here-and-now. In this respect, trust and hope differ from confidence, despair, and power in the limited sense, in that the former resemble dispositional power in drawing attention to the plane of the virtual.

Unlike confidence, but like power, the display of trust may be understood as a capacity or an ability to do something. When showing trust, we concurrently affect the dispositions of others. Entrusting ourselves to others, we hand over part of ourselves to others and thus let others gain power over us. As a consequence, we risk being let down, disappointed, or even betrayed. Precisely because we entrust ourselves to others and take risks, however, we concomitantly begin to affect others to (the) effect that what we fear becomes less likely to happen. In some odd sense, showing trust and thereby delivering oneself over to others has a challenging side to it; a challenge that we must measure up to in the world that we begin constructing together in this way. By exposing part of ourselves or our possessions to others, we act and thereby actively issue the ethical demand that these others should prove 
themselves worthy of our trust, and should live up to it, whether they actually end up doing this or not (Løgstrup 1997: 8-28).

In this respect, showing trust follows the logic of gift-giving as it has been articulated in anthropological studies, especially by Mauss and Levi-Strauss (Mauss 1995; Levi-Strauss 1949). When giving gifts to others, we start creating a total social reality that interferes with and, at least partly, sets aside individual interests. We begin to establish a social bond, in the form of a "moral contract", obliging the participants to enter a reciprocal exchange in which they should, in the long run, preferably give more than they have received, as they return part of their possessions and themselves (Mauss 1995: 148, 271). If gift-giving is habitually associated with freedom, luxury, and generosity, it should equally be understood as a juridically and ethically very demanding social activity.

Similarly, when we hand over part of our possessions or of ourselves by entrusting ourselves to others, we place them under the obligation to take care of and reciprocate this peculiar kind of gift in a proper way. By placing their future activity under the auspices of this obligation, we are able to affect others in ways that effect a change in their dispositions to act. We are able to influence the way people relate to themselves and behave, in and by the way we relate to ourselves as we exhibit trust. Consequently, the resolve to show trust is also a way to exercise power. In particular, it is an exercise of power that is able to take human independence actively into account to make the best of self-management. Still, whether we are prepared to take the risk of adopting a trusting attitude also depends to some extent on whether past and present experiences give us reason to trust. A trusting attitude must be based on relevant supportive knowledge if trust is to be more than just a starry-eyed confidence, or an obstinate resolve to maintain a certain moral stance by cherishing trust as a universal fixed ethical value (Luhmann 1973). Even when explicitly 
voiced as trust in the new, trust maintains a close relationship to knowledge (Luhmann 1973, Misztal 1998). ${ }^{\mathrm{ix}}$

So, on the basis of the account given, the decision to show trust may be conceived of as actively endorsed risk-taking, adopted in anticipation of an additional gain that is not otherwise to be obtained. Up to a point, trust is motivated by relevantly corroborating knowledge and experience. Beyond that, the resolve to adopt a trusting attitude is motivated by hope as an inveterate being affected by a coming into being that transcends the conditions given. In addition, such a stance is supported by the expectation that by handing over a part of ourselves or of our possessions to others in this way, we begin establishing a binding social contract; a mutual ethico-juridical obligation to attend to this gift-giving in a proper way, also by preferably rendering more than we have received. Since this mutual obligation affects the dispositions to act and works as a virtual force that is operative and felt through its effects, showing trust can most decidedly be conceived of as a way to exercise power. Undoubtedly, actively trusting people has the capacity to affect them and make them behave in ways they would not otherwise behave (Dahl 1957).

\section{Trust and Indirect Potency: The Fall from Grace as the Inception of Humanity and}

\section{Human (Inter)dependency}

The notions of power, trust, freedom, and gift-giving suggested here are closely related to the issues of potency and impotence. Understood, respectively, as the experienced capacity or the incapacity to bring about a particular result directly by an act of will, potency and especially impotence are, first and foremost, themes played out most notoriously in their male, especially physical, configurations. A closer inspection reveals, however, that this relatively simple phallic mirror-image is apparently inadequate if we are to grasp the more subtle 
workings of potency. As a consequence, more interdependent "female" versions of potency are also called for and should be envisaged in order for us to grasp the more subtle workings of power and trust.

Direct potency may at first seem to count among the most paradisiacal of the joys man can experience, at least according to St. Augustine. When embarking on a quest for the self and its relationship to itself and others, the church father imagined that in the perfect prelapsarian state of Eden, Adam must have been a creature that "enjoyed absolute power" over all his members in the same way that we move our articulate members, such as hands, feet, and fingers (Augustine 1998: xiv, 23-4). Having, accordingly, direct authority even over the tumescence of his sexual organ, man was then able to perform at will. Since it was to be perceived as a direct result of the will, the performance of the sexual act in the original ideal state was exempted from the impurities of lust and sin.

However, as soon as man committed the original sin of transgressing "divine commandment" and "despising ... the authority of God" (Augustine 1998: xiv, 14-15), in retribution, the expulsion from Paradise implies his exposure to a similar disobedience within himself. He begins to experience his own lust in the form of the rise of an insubmission, and as the root of sin, and as a consequence the sexual act tends to become unclean and sinful. From that point on, asserts St. Augustine, man experiences that "his mind and his flesh do not obey his will" but instead begin to dominate his will. "[H]e wishes [that] which he cannot do," and he is unable to do what he wills (Augustine 1998: xiv, 15).

And so, according to St. Augustine, original sin opens a cleft in both the human body and in the "body politic" at large. As a result, both have ceased to conform to the image of a potent, irrigated, and unbroken phallus. Instead, in their present postlapsarian state the morphology of the human body and the political body seem to mirror the shape of a pudendal cleft separating and joining the female labia (Irigaray 1974). The cleft indicates that each body tends to be in 
disagreement with itself, and that both may be mutually inconsistent with one another. This disagreement shakes the established order and opens up the prospect that it may be reversed. From the perspective of those "originally" in power, the salient feature of the fall from grace is the absence of a potent order of control. The postlapsarian human condition entails an essential dependency on extrinsic factors that cannot be dominated, and therefore a constant dread of impotence.

Parallel to this, however, the very same "original" involuntary erection—which implies the impotence of will, control, and direct action — gives birth to an alternative order. It marks the beginning of a "how-are-you-ness" or Sich-befinden as an irreducible dimension and issue in human life (cf. Heidegger 1979 on Befindlichkeit, esp. §§134-6). This opens up the experience of finding ourselves situated with regard to/in a certain mood, resulting from the fact that we have already been affected in certain uncontrollable ways that dispose us to behave and express ourselves in certain ways.

Another outcome of this is that the "fall from grace" also raises the issue of how to conduct ourselves and reaffirm our will with regard to this complex of affectivity through which we sense ourselves as situated in and exposed to a world that is irreducibly external and foreign. As St. Augustine seems to have sensed in his own very acute way, this dependency indicates an "uncanniness of the ordinary" (Cavell 1988; cf. also Heidegger 1980a). It is the experience of "not being at home in the world" (Heidegger 1979: 223), the awareness that we may be let down by unfamiliar and alien forces, or that they may take us where we would not like to go. This experience of precariousness raises the issue of how to find the courage to trust unfamiliar bodily and social forces that we cannot control. Likewise, the dread of losing control and the fear of falling raises the question of the extent to which we actually could, and should, do so. With the involuntary erection of the "how-are-you-ness", a responsiveness to external relations and forces comes to the fore that manifests the irreducibility of, and the 
exposure to, the social realm and its alienness. When turning to trust, we actively and openly hold on to a responsiveness to external forces.

However, social affectivity opens up the possibility of potency in a wider sense, as responsiveness curtails the scope of direct potency in these ways and makes impotence an ever-present virtual challenge. It is potency understood as the capacity to bring about results by an act of will, be it directly or indirectly. This power is not the power of the will, but a mediated potency, depending on complex responses and relationships. It implies the ability to be affected and the capacity to effect indirectly, by associating with, being affected by, and affecting initially unfamiliar dispositions, our "own" as well as those of others. Even as the expulsion from Paradise opens a wound in being that forces Adam and Eve to face freedom in the modern, challenging sense described, the very same fall from grace enables us to take comfort in the fact that we may express and regain ourselves post hoc by taking refuge in that which is foreign in ourselves and others. By accepting and trying to attain maturity with regard to that which is insubmissive in ourselves and others, we may gain power and potency in a wider indirect sense, transgressing the immediate scope of our will. However, in order to seek out this potentiality to become more potent in this unvolitional sense, we must be prepared to lose control and chose to take risks, and accordingly risk being disappointed. Indirect potency presupposes the ability to trust not only the new, but also the unfamiliar and the foreign, hoping despite the possibility of despair.

As described in his autobiography (Mandela 1994: 457-59) and further analyzed in this journal by James H. Reid (Read J.H. 2010, 317-339), Nelson Mandela made a risky decision when he resolved to begin secret discussions with the National Party Government of South Africa in 1985, without getting the approval of his own African National Congress (ANC). Starting from the experience of an almost complete state of impotence, or direct incapacity, in his solitary confinement in Pollsmore Prison, Mandela decided to take the first step, despite 
none of ANC's preconditions for talks had been met. In this way, he took substantial risks and showed trust in his opponents, especially State President F.W. de Klerk, where other members of the ANC did not seem willing to do so. Concomitantly, Mandela showed leadership, not only within and of his own organization, but on behalf of South Africa as a whole. Mandela sincerely believed that civil war was the likely outcome without his risk-taking leadership and that both parties stood to gain from negotiations. As a result of both his anticipatory attitudes of both fear and hope, he also took the resolve to "move out ahead of his flock" (Mandela 1994: 459), to set off in a new direction in order to achieve a new direction for himself and others.

When doing so, Mandela openly faced the high risk inherent in adopting this trusting attitude. He realized that he was unable to control the process that he had set in motion. Consequently, he had to be aware that his expectations might be shattered. Indeed, his willingness to take the first step might lead his opponents to suspect weakness on his part and thus escalate their demands (Read J.H. 2010, 317-339: 318). Alternatively, the members of his own flock might also decide renounce him, especially if negotiations went awry. In fact, Mandela actively faced this possibility, also as a possible solution, given that "in the case of failure it would best serve the interests of the cause to which he had devoted and risked his life, to allow himself to be renounced as an irrelevant old man without authority" (Read J.H. 2010, 317 339: 318). In the last resort, he might end up in a position of utter abandonment, solitude and impotence - a situation not unlike King Lear's.

With his initial display of trust as an active risk-taker, he was unlike King Lear. However, Mandela focused on the yet-to-be as it could be mediated through the given here-and-now and thus drew attention to the plane of the virtual as an undertaking that one can commit oneself to. In this way, he affected the dispositions of others, including those of his opponents. By giving his trust as a gift to others, Mandela managed to initiate an exchange that set aside 
what seemed to be in immediate self-interest and to oblige the participants to enter into the logics of mutual trust and gift-giving. Adopting a trusting attitude, Mandela thus managed to exercise power, despite, but certainly also precisely due to the fact that he seemed in a minority position. From this position he even had the audacity to claim and demonstrate that political power should not necessarily be regarded as an inherently zero-sum game, in the sense that gains for some by definition entail equivalent losses for others (Read 2012, 5-31). Instead, he managed to practice power as a variable sum game, in which mutual gains and losses of power are possible, without equivalent losses elsewhere; he thus managed to show that this was possible even in a context of conflict.

In the course of events, Mandela showed peculiar aptitude for leadership and a managed to stand forth as a very potent leader. Still, he did so precisely by recognizing and respecting extrinsic human factors beyond his control and taking advantage of this dependency. Accepting the challenges and possibilities in indirect potency, Mandela was able to gain power and potency in a wider mediated sense. He managed to become and stay a “transformational leader" that made a difference (Read J.H. 2010, 317-339: 337). However, he owed this effect not primarily to a "extra-ordinary (ausseralltäglich)", "magic" and godlike quality, a charisma or will, that he was personally in possession of and that his followers identified with and that they abandoned themselves to (Weber and Winckelmann 1980: 140). Instead, Mandela's effect was to a large extent due to the fact that he showed a peculiar aptitude for changing the attitudes in the people around him. He began by recognizing a fall from grace, insofar as it entailed that human beings could only express themselves post hoc, by taking refuge to that which is at first foreign to themselves; and he made this interdependency present as a shared condition. Starting from a voluntary assumption of human interconnectedness as a basis for exercising power, Mandela managed to effect a resurrection of the human. 


\section{Acknowledgements}

Thanks to Kasper Worm Petersen for proficient assistance. I also thank two anonymous reviewers for their challenging remarks, as I am grateful to Mark Haugaard, editor of the Journal of Political Power, for his encouragement and support.

\section{Notes}

\footnotetext{
${ }^{i}$ Email: sra.lpf@cbs.dk

ii In fifteenth-century Europe, control was habitually associated with the activity of checking accounts and
} verifying that they were right by comparison with an existing duplicate register that they were supposed to conform to (Onions 1966: 211).

iii Dahl makes this point: “for the assertion 'C has power over' $\mathrm{R}$, one can substitute the assertion, 'C's behaviour causes R's behavior' " (Dahl 2002: 16).

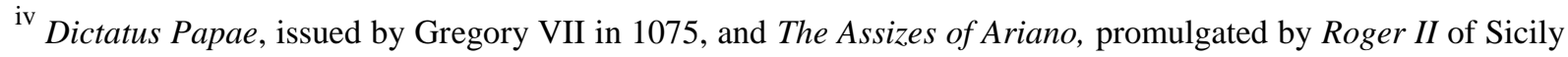
in 1140, represent early examples of this development (Raffnsøe: 2003). In his capacity as king of Sicily, the German Emperor Frederick II later published the more comprehensive Liber augustalis in 1231 (Frederick II 1971).

" In its earliest, most original form, the term "status" meant "a state of peace", (cf. Luhmann 1989: 83). Only later did the term come to refer to the actor establishing and guaranteeing a peaceful state, if necessary by recourse to force.

vi At one end of the spectrum, "someone" or "somebody" could be any(-)body in movement or activity. At the other end of the spectrum, the being affected, by someone or by myself, could eventually be me. To simplify matters, however, during the rest of this chapter I shall confine myself to focusing on discussing the capacity to affect others.

vii The earlier English "translation" of Foucault's French text somewhat misleadingly reads: "guiding the possibility of conduct" (Foucault 1982: 221).

viii The earlier English "translation" of the French text reads: "the intransigence of freedom" and "the recalcitrance of the will” (Foucault 1982: 221-2). 
${ }^{\text {ix }}$ This is equally true of hope. To remain a true conscience of tomorrow, hope, as the expectancy of possibilities yet to come, must also be based on knowledge. If not, hope risks becoming mere reverie, be it as "a disposition of the soul to persuade itself that what it covets will happen (L'espérance est une disposition de l'âme à se persuader que ce qu'elle desire adviendra)" (Descartes 1996: 203; own trans., SR) or as "eine JenseitsHoffnung," an "evil of evils" capable of making those who suffer hold out, but also likely to make them put up with the conditions given (Nietzsche 1979: 1183).

${ }^{\text {ix }}$ At the same time, it is quite misleading to understand knowledge-seeking as an activity exclusively concerned with the past and the present. Investigations in philosophy and anthropology have led us to consider hope as an implicit "common operative in all knowledge formation" in order to confront the "most fundamental problem" concerning knowledge, which is "what knowledge is for" (Miyazaki 2004: 9).

\section{Notes on contributor}

(Sverre Raffnsфe holds a doctoral degree in philosophy and a position as Professor of Philosophy with the Department of Management, Politics, and Philosophy at Copenhagen Business School. He is editor-in-chief of Foucault Studies and research director of The Human Turn (HUMAN) and Management of Self-Management, research programs funded by the Velux Foundation. In addition to Foucault: A Comprehensive Introduction (forthcoming 2014), Nietzsches "Genealogie der Moral" (2007), and Coexistence without Common Sense, Vol. I-III (doctoral dissertation 2002), he is the author of books and articles on philosophical aesthetics, management philosophy, social philosophy, and recent French and German philosophy. Academic home page: uk.cbs.dk/staff/raffnsoe. Personal home page: http://www.xn--raffnse-v1a.com)

\section{References}

Ahmed, Sara. 2004. The Cultural Politics of Emotions. Edinburgh: Edinburgh University Press.

Allen, Amy. 1999. The Power of Feminist Theory: Domination, Resistance, Solidarity. Boulder, Colo.: Westview Press.

Arendt, Hannah. 1970. On Violence. New York: Harcourt, Brace, Jovanovich. 
Augustine. 1998. The City of God Against the Pagans. Cambridge: Cambridge University Press.

Austin, John. 1968. The Province of Jurisprudence Determined and he Uses of the Study of Jurisprudence. London: Weidenfeld and Nicolson.

Austin, John L. 1980. How to Do Things with Words. Oxford: Oxford University Press.

Aquinas, Thomas. 1974. “On Princely Government to the King of Cyprus [De regimine principum ad regem cypri]”. In Aquinas. Selected Political Writings, ed. Alessandro P. D’Entreves. Oxford: Oxford University Press.

Barnes, Barry. 1988. The Nature of Power. Urbana: University of Illinois Press.

Bentham, Jeremy. 1977. A Comment on the Commentaries and a Fragment on Government. London: The Athlone Press.

Bentham, Jeremy. 1983. “Constitutional Code.” In The Collected Works of Jeremy Bentham, vol. 1, eds. R. Rosen, and J. H. Burns. Oxford: Clarendon Press

Bloch, Ernst 1985. Das Prinzip Hoffnung. Band I-III. Frankfurt am Main: Suhrkamp Verlag.

Butler, Judith 2005. Giving an Account of Oneself. New York, NY: Fordham University Press.

Cavell, Stanley. 1988. In Quest of the Ordinary. Chicago, IL: University of Chicago Press.

Dahl, Robert A. 1957. "The Concept of Power.” Behavioral Science 2, no. 3: 201-15.

Dahl, Robert A. 2002. "Power.” In Power: A Reader, ed. Mark Haugaard. Manchester \& New York: Manchester University Press.

Dean, Mitchell. 2012. "The Signature of Power". Journal of Political Power 5, no. 1:101-117. 
Descartes, René. 1996. Les passions de l'âme. Paris: Flammarion.

Deleuze, Gilles. 1991. Bergsonism. New York, NY: Zone.

Deleuze, Gilles. 1996. “L'actuel et le Virtuel.” In Dialogues, eds. Gilles Deleuze and Claire Parnet. Paris: Flammarion.

Derrida, Jacques. 1967. De la Grammatologie. Paris: Les Éditions de Minuit.

Derrida, Jacques. 1972. “Ousia et Grammè.” In Marges de la philosophie. Paris: Les Éditions de Minuit.

Foucault, Michel. 1976. La Volonté de Savoir. Paris: Editions de Gallimard.

Foucault, Michel. 1982. “Afterword: The Subject and Power.” In In Hubert L. Dreyfus and Paul Rabinow: Michel Foucault: Beyond Structuralism and Hermeneutics. Chicago, IL: The University of Chicago Press.

Foucault, Michel. 1984. "Deux Essays sur le Sujet et le Pouvoir.” In Michel Foucault: Un Parcours Philosophique: Avec un Entretien et Deux Essays de Michel Foucault, eds. Hubert L. Dreyfus and Paul Rabinow. Paris: Éditions Gallimard.

Foucault, Michel. 2003. "Society Must Be Defended:” Lectures at the Collège de France 1975-76. Basingstoke: Macmillan Publishers Limited.

Frederick II. 1971. The Liber Augustalis: or, Constitutions of Melfi, Promulgated by the Emperor Frederick II for the Kingdom of Sicily in 1231. Syracuse, NY: Syracuse University Press.

Hart, Herbert L.A. 1979. The Concept of Law. Oxford: The Clarendon Press. 
Haugaard M. 2012. 'Editorial: Reflections upon Power Over, Power to, Power with, and the Four Dimensions of Power. Journal of Political Power 5, no. 3:353-358.

Haugaard M. 2012. "Rethinking the Four Dimensions of Power: Domination and Empowerment. Journal of Political Power 5, no. 1:33-54.

Hegel, Georg W. F. 1972. Grundlinien der Philosophie des Rechts. Frankfurt am Main: Ullstein.

Heidegger, Martin. 1976. Platons Lehre von der Wahrheit. Bern: Francke Verlag.

Heidegger, Martin. 1979. Sein und Zeit. Tübingen: Niemeyer.

Heidegger, Martin. 1980a. “Der Ursprung des Kunstwerkes.” In Holzwege. Frankfurt am Main: Vittorio Klostermann.

Heidegger, Martin. 1980b. “Die Zeit des Weltbildes.” In Holzwege. Frankfurt am Main: Vittorio Klostermann.

Hobbes, Thomas. 1979. Leviathan. Middlesex: Penguin Books.

Irigaray, Luce. 1974. Speculum de l'autre Femme. Paris: Éditions de minuit.

Kant, Immanuel. 1976a. Grundlegung zur Metaphysik der Sitten. In Werkausgabe, vol. VII, ed. W. Weischedel. Frankfurt am Main: Suhrkamp.

Kant, Immanuel. 1976b. Metaphysik der Sitten. In Werkausgabe, vol. VIII, ed. W.

Weischedel. Frankfurt am Main: Suhrkamp.

Kant, Immanuel. 1976c. Kritik der Urteilskraft. In Werkausgabe, vol. X, ed. W. Weischedel. Frankfurt am Main: Suhrkamp. 
Kant, Immanuel. 1976d. "Beantwortung der Frage: Was ist Aufklärung." In Werkausgabe, vol. X, ed. W. Weischedel. Frankfurt am Main: Suhrkamp.

Levi-Strauss, Claude. 1949. Les Structures Élémentaires de la Parenté. Paris: Presses Universitaires de France.

Locke, John. 1963. Two Treatises of Government. Cambridge: Cambridge University Press.

Luhmann, Niklas. 1973. Vertrauen: Ein Mechanismus der Reduktion sozialer Komplexität. Stuttgart: Verdinand Enke Verlag.

Luhmann, Niklas. 1989. "Staat und Staatsräson im Übergang von traditionaler Herrschaft zu moderner Politik.” In Gesellschaftsstruktur und Semantik, vol. 3. Frankfurt am Main: Suhrkamp Verlag.

Løgstrup, Knud E. 1997. The Ethical Demand. Notre Dame, IN and London: University of Notre Dame Press.

Machiavelli, Niccolò. 1977. The Prince. New York and London: W.W. Norton \& Company.

Mandela, Nelson. 1994. Long Walk to Freedom : The Autobiography of Nelson Mandela. Boston: Little, Brown.

Massumi, Brian. 2002. Parables for the Virtual. Durham and London: Duke University Press.

Mauss, Marcel. 1995. “Essai sur le Don.” In Sociologie et Anthropologie. Paris: Presses Universitaires de France.

Misztal, Barbara A. 1996/98. Trust in Modern Societies. Cambridge: Polity Press.

Miyazaki, Hirokazu. 2004. The Method of Hope: Anthropology, Philosophy, and Fijian Knowledge. Stanford, CA: Stanford University Press. 
Morriss, Peter. 2012. "A Response to Pamela Pansardi." Journal of Political Power 5, no. 1:91-99.

Morriss, Peter. 1987/2002. Power: A Philosophical Analysis. Manchester and New York: Manchester University Press.

Nye, Josep S. 2010. "Power and Leadership." In Handbook of Leadership Theory and Practice, edited by Nitin Nohria and Rakesh Khurana. Boston, Massachusetts: Harvard Business Press:305-32.

Nye, Joseph S. 2008. The Powers to Lead. Oxford; New York: Oxford University Press.

Nietzsche, Friedrich. 1979. Der Antichrist: Fluch auf das Christentum. In Werke III, Friedrich Nietzsche. Frankfurt am Main, Berlin; Wien: Ullstein Verlag.

Onions, Charles T. 1966. Oxford Dictionary of English Etymology. Oxford: Oxford University Press.

Pansardi P. 2012. "Power To and Power Over: Two Distinct Concepts of Power?" Journal of Political Power 5, no. 1:73-89.

Pansardi, Pamela. 2012. "On Abilities and Power Again: A Reply to Peter Morriss.” Journal of Political Power 5, no. 3:493-497.

Raffnsøe, Sverre. 1996. “Reorganizing Society.” In Law, Justice and the State IV, eds. Mikael M. Karlsson and Olafur P. Jonsson. Berlin: Archiv für Rechts- und Sozialphilosophie. Available at http://cbs.academia.edu/SverreRaffns\%C3\%B8e

Raffnsøe, Sverre. 2001. "Order Ordealed: Norms and Social Coherence in the Age of Law." Readings in Philosophy and Science Studies, 1: 120-46. Available at http://cbs.academia.edu/SverreRaffns\%C3\%B8e 
Raffnsøe, Sverre. 2002. “English Summary.” In Sameksistens Uden Common Sense, Doctoral Dissertation, vol. 3, Sverre Raffnsøe. Copenhagen: Akademisk Forlag: 372-414.

Raffnsøe, Sverre. 2003. “The Rise of the Network Society”. Copenhagen: MPP WP 24/2003. Available at http://ep.lib.cbs.dk/paper/ISBN/8791181674

Raffnsøe, Sverre. 2010. "The Obligation of Self-management: The Social Bonds of Freedom.” In Villum Foundation \& Velux Foundation. Annual report 2009, eds. K. J. Petersen and H. Tronier. Søborg: Villum Foundation \& Velux Foundation.

Read James H. 2010. "Leadership and Power in Nelson Mandela's Long Walk to Freedom.” Journal of Political Power 3, no. 3:317-339.

Read, James H. 2012. "Is power zero-sum or variable-sum? Old arguments and new beginnings." Journal of Political Power 5, no. 1:5-31.

Rousseau, Jean-Jacques. 1964. Du Contrat Social. Ecrits politiques. Paris: Gallimard.

Ryle, Gilbert. 1966. The Concept of Mind. Middlesex: Penguin Books.

Shakespeare, William. 1977. "King Lear.” In The Complete Works of William Shakespeare. London: Muirray Sales \& Service Co.

Solomon, Robert C., and Fernando Flores. 2003. Building Trust in Business, Politics, Relationships, and Life. Oxford, New York: Oxford University Press.

Weber, Max, and Winckelmann, Johannnes. 1980. Wirtschaft und Gesellschaft : Grundriss der verstehenden Soziologie. Tübingen: J.C.B. Mohr.

Wicks, Andrew C., Shawn L. Berman, and Thomas M. Jones. 1999. "The Structure of Optimal Trust: Moral and Strategic Implications." The Academy of Management Review 24, no. 1:99-116. 
Wren, Daniel A. 2005. The History of Management Thought. Hoboken, N.J.: Wiley. 